\title{
Up-regulated NRIP2 in colorectal cancer initiating cells modulates the Wnt pathway by targeting ROR $\beta$
}

Zhenzhen Wen ${ }^{1,6+}$, Tianhui Pan ${ }^{1 \dagger}$, Saisai Yang ${ }^{1}$, Jingwen Liu', Haiying Tao², Yiming Zhao ${ }^{1}$, Dingting Xu', Wei Shao ${ }^{3}$, Jia Wu' ${ }^{1}$, Xiyong Liư ${ }^{4}$, Yongjiang Wang ${ }^{1}$, Jianshan Mao ${ }^{1,5^{*}}$ and Yongliang Zhu ${ }^{1,5^{*}}$

\begin{abstract}
Background: Colorectal cancer remains one of the most common malignant tumors worldwide. Colorectal cancer initiating cells (CCICs) are a small subpopulation responsible for malignant behaviors of colorectal cancer. Aberrant activation of the Wnt pathways regulates the self-renewal of CCIC. However, the underlying mechanism(s) remain poorly understood.

Methods: Via retroviral library screening, we identified Nuclear Receptor-Interacting Protein 2 (NRIP2) as a novel interactor of the Wnt pathway from enriched colorectal cancer colosphere cells. The expression levels of NRIP2 and retinoic acid-related orphan receptor $\beta$ (RORß) were further examined by FISH, qRT-PCR, IHC and Western blot. NRIP2 overexpressed and knockdown colorectal cancer cells were produced to study the role of NRIP2 in Wnt pathway. We also verified the binding between NRIP2 and ROR $\beta$ and investigated the effect of ROR $\beta$ on CCICs both in vitro and in vivo. Genechip-scanning speculated downstream target HBP1. Western blot, ChIP and luciferase reporter were carried to investigate the interaction between NRIP2, ROR 3 , and HBP1.

Results: NRIP2 was significantly up-regulated in CCICs from both cell lines and primary colorectal cancer tissues. Reinforced expression of NRIP2 increased Wnt activity, while silencing of NRIP2 attenuated Wnt activity. The transcription factor ROR $\beta$ was a key target through which NRIP2 regulated Wnt pathway activity. ROR $\beta$ was a transcriptional enhancer of inhibitor HBP1 of the Wnt pathway. NRIP2 prevented ROR $\beta$ to bind with downstream HBP1 promoter regions and reduced the transcription of HBP1. This, in turn, attenuated the HBP1-dependent inhibition of TCF4-mediated transcription.
\end{abstract}

Conclusions: NRIP2 is a novel interactor of the Wnt pathway in colorectal cancer initiating cells. interactions between NRIP2, RORß, and HBP1 mediate a new mechanism for CCIC self-renewal via the Wnt activity.

Keywords: Colorectal cancer initiating cells, Self-renewal, Non-canonical Wnt pathway, NRIP2, ROR $\beta$, HBP1

\section{Background}

Colorectal cancer remains one of the most common malignant tumors in the world [1]. Studies have indicated that colorectal cancer consists of heterogeneous populations of cells differing in gene expression and growth capacities [2,3]. CCICs are a small subpopulation of cells within colorectal tumors that can self-renew,

\footnotetext{
* Correspondence: jshmao@zju.edu.cn; drylzhu@163.com

${ }^{\dagger}$ Equal contributors

'Laboratory of Gastroenterology, Second Affiliated Hospital of Zhejiang

University School of Medicine, Jiefang Road 88\#, Hangzhou, Zhejiang 310009,

China

Full list of author information is available at the end of the article
}

differentiate into multiple lineages, and drive tumor growth [4, 5]. Among the CCIC properties, the selfrenewal ability, which allows the cells to replicate is a crucial step for CCICs that is responsible for maintaining their homeostasis and malignant behaviors [6-8]. It is therefore of particular importance to clarify which molecules are abnormally activated during CCIC selfrenewal.

There are several pathways participating in the regulation of the self-renewal of CCICs. Notch signaling plays an important role in promoting CCIC self-renewal. The Notch effector Hes1 up-regulates the expression of the 
stem-related molecules CD133, ABCG2, Nanog, and ALDH1 and increases the amount of CD133+ and stemlike SP cells within colorectal cancer cells [9]. miR-34a targeting Notch1 promotes the differentiation of CCICs [10]; The BMP pathway maintains a stem cell selfrenewal balance by inhibiting the Wnt pathway. The zinc-finger transcription factor GATA6 is a crucial regulation factor connecting the Wnt and BMP pathways. Competing with $\beta$-catenin/TCF4, GATA6 binds to a distal regulatory region of BMP4, decreases the threshold of the BMP pathway and enables the self-renewal of CCICs [11]. Colorectal cancer cells also have a high level of activity of HedgeHog (HH)-GLI signaling, and the self-renewal of CCICs relies on the direct function of HH-GLI activity in xenograft tumors [12]; Akt can activate 14-3-3zeta in the beta-catenin complex, which contributes to the stabilization and nuclear translocation of $\beta$-catenin, thus facilitating CCSC self-renewal by activating Wnt [13]. Akt also phosphorylates Oct4 to promote iPS factor transcription [14]. Among these pathways, the abnormal activation of the Wnt pathway is one of the most critical events in the tumorigenesis and development of colorectal cancer and plays a key role in maintaining the self-renewal of CCICs [15-18]. Aberrant activation of the Wnt pathway occurs in $>90 \%$ of colorectal cancers [19]. Strong Wnt activation is found in cancerous intestinal epithelial $\mathrm{ALDH}^{+}$initiating cells in ulcerative colitis in addition to $\mathrm{CD} 133^{+}$initiating cells in animal tumorigenesis models [20, 21]. Hence, Wnt activity is an important target for inhibition of the selfrenewal of CCICs.

The Wnt pathways include canonical ( $\beta$-catenindependent) and non-canonical ( $\beta$-catenin-independent) pathways. In the canonical Wnt pathway, the ligands Wnt1, Wnt3a, and Wnt8 can bind the Frizzled receptor and LRP5/6 co-receptor on the cell surface, promoting the recruitment of Disheveled (Dvl) from the cytoplasm to the membrane. This, in turn, induces GSK-3 $\beta$ phosphorylation, which suppresses $\beta$-catenin degradation. Free $\beta$-catenin then accumulates in the cytoplasm and translocates to the nucleus, where it interacts with LEF and TCF to activate the transcription of downstream targets, including $M Y C, C C N D 1, A X I N 2$, and $L E C T 2$, etc. $[22,23]$. The non-canonical pathways mainly include the PCP pathway and $\mathrm{Wnt} / \mathrm{Ca}^{2+}$ pathway. In the PCP pathway, Wnt5a and other ligands bind to Frizzled and ROR2/PTK7 co-receptors, inducing a signaling cascade involving RhoA, Rac, Cdc42, and JNK, which act on the cytoskeleton $[24,25]$. In the $\mathrm{Wnt} / \mathrm{Ca}^{2+}$ pathway, Wnt ligands combine with Frizzled, leading to PKC and CamKII activation, which regulate target transcription $[26,27]$. Thus, the non-canonical Wnt pathways maintain the self-renewal capacity of tumor cells and promote their tumorigenic ability by influencing canonical
Wnt pathway activation at different levels $[19,26]$. However, the mechanism of Wnt pathway activation in CCICs is still unclear; especially in terms of how noncanonical Wnt signaling molecules affect the canonical pathway.

Here, we identified NRIP2 as a novel molecule that collaborates with ROR $\beta$ and HMG box-containing protein 1 (HBP1) to modulate Wnt activity.

\section{Methods \\ Cancer tissues and CDNA database}

All fresh primary colorectal cancer tissues were collected in the Second Affiliated Hospital of the Zhejiang University School of Medicine, with Institutional Review Board approval and informed consent provided by the patients (Reference number: R2014-041). All 565 cDNA genechip databases derived from patients with colorectal cancer were from the City of Hope National Medical Center of USA.

\section{Cell culture}

Colorectal cancer SW620, HT29, and LoVo cells; gastric cancer SGC7901 cells; and 293 T cells were purchased from The Cell Bank of Chinese Academy of Sciences at the Shanghai Institute of Cell Biology. Colorectal cancer cells which were derived from primary colorectal cancer tissue were cultured in DMEM/F12 medium (Gibco, Gaithersburg, MD, USA) [28]; SW620 cells were cultured in L-15 medium (Gibco); HT29 cells were cultured in Macoy's 5A medium (Gibco); Lovo cells were cultured in F-12 medium (Gibco); SGC7901 and P1 cells were cultured in RPMI-1640 medium (Cellgro, Manassas, USA); and $293 \mathrm{~T}$ cells were cultured in DMEM highglucose medium (Gibco). All media were supplemented with $100 \mathrm{U} / \mathrm{ml}$ penicillin, $100 \mu \mathrm{g} / \mathrm{ml}$ streptomycin, and $10 \%$ fetal bovine serum (Gibco). The cells were cultured at $37{ }^{\circ} \mathrm{C}$ in a humidified atmosphere containing $5 \% \mathrm{CO}_{2}$.

\section{Culturing and counting spheres}

Colorectal cancer cell lines and primary colorectal cancer cells were seeded into 24-well low-adhesion plates (Corning, NY, USA) at 200 cells/well and cultured in serum-free sphere medium (containing $1 \times \mathrm{B} 27,20 \mu \mathrm{g} / \mathrm{L}$ EGF, $20 \mu \mathrm{g} / \mathrm{L}$ bFGF, $4 \mathrm{mg} / \mathrm{L}$ insulin, $0.4 \% \mathrm{BSA}$, and $200 \mathrm{IU} / \mathrm{mL}$ streptomycin). These cells were grown in the presence or absence of Wnt Pathway Inhibitor XI, Wnt/ $\beta$-catenin Inhibitor, Cardamonin (Merck, Germany), or the Wnt activator recombinant Wnt3a (R\&D Systems, MN, USA) for 7-14 days at $37{ }^{\circ} \mathrm{C}$ in a humidified atmosphere containing $5 \% \mathrm{CO}_{2}$. After the incubation period, the spheres were dilute passaged for an additional 1 week and the number of spheres was counted manually. 


\section{Organoid culture}

The above colosphere cells were digested with $0.25 \%$ trypsin and produced single cells using a $40 \mu \mathrm{M}$ cell strainer (BD, USA). One-hundred cells in $40 \mu \mathrm{L}$ of medium were mixed well with $70 \mu \mathrm{L}$ of growth factordeficient Matrigel (Biocoat, USA) and inoculated on the rim of a 24-well plate at $37{ }^{\circ} \mathrm{C}$ for $1 \mathrm{~h}$. Subsequently, $1 \mathrm{~mL}$ of serum-free sphere medium was added for 5-7 days in a humidified atmosphere containing $5 \% \mathrm{CO}_{2}$.

\section{Creation and screening of a retroviral CDNA library}

Total RNA was extracted from SW620 colosphere cells using an RNeasy Kit (Qiagen, Germany). A ZAP cDNA Library Preparation Kit (Stratagene, CA, USA) was used to prepare cDNA, according to the manufacturer's instructions. Briefly, RNA was reverse transcribed using a ZAP hemi-methylation primer. Next, double-stranded cDNA was synthesized in vitro, digested with XhoI/ EcoRI endonucleases, cloned into the modified pLXSN vector (Clontech Laboratories, CA, USA), and transformed into Escherichia coli DH5 $\alpha$ cells (Stratagene). The plasmids were then extracted and transfected into PT67 packaging cells (Clontech) to produce the recombinant retroviral particles. Before infection, CD133+ and CD44+ SGC7901 cells were removed by magneticactivated cell sorting (Miltenyi, Germany), and the remaining SGC7901 cells were infected (multiplicity of infection is 20) and cultured in a serum-free low adhesion culture system for 7 days. Colospheres were then collected and digested into a single cell suspension and cloned by limiting dilution, and the clonal cells were further propagated. The Top/Fop flash reporter assay was used to determine Wnt activity. Genomic DNA from cells with obvious changes in Wnt activity was extracted using a DNA extraction kit (Qiagen, Germany), and PCR was used to amplify the inserted DNA fragment with primers from pLXSN plasmids. Finally, DNA sequencing was performed to verify the clones.

\section{mRNA hybridization}

A QuantiGene @ ViewRNA ISH Tissue Assay Kit (Affymetrix, USA) was used for RNA hybridization according to the kit instructions. Briefly, RORB and NRIP2 were used as TYPE1 probes, and GAPDH was used as a control probe. After staining the nucleus with DAPI or Hoechst 33342 dye (Invitrogen, Carlsbad, CA), the distribution and expression of RORB and NRIP2 were observed under a confocal microscope (Carl Zeiss Jena, Germany).

\section{Assessing tumor sizes in mice}

With approval from a local animal protection association, NOD/SCID and naked Balb/c mice were purchased from the Shanghai Laboratory Animal Center (Chinese Academy of Sciences) and bred in specific pathogen-free animal housing at the Laboratory Animal Research Center (Zhejiang Traditional Chinese Medical University). The mice were randomized into groups (5 mice/group for each tumor cell dose) and subcutaneously inoculated in their backs with $0.3 \mathrm{~mL}$ of different numbers of SW620 cells. The formation and growth of the transplanted tumors were observed, and the tumor sizes were recorded. The tumor volumes were calculated as $4 / 3 \pi[1 / 2 \times$ (long diameter $/ 2+$ short diameter $/ 2)]^{3}$.

\section{Measuring Wnt pathway activity}

Wild-type and mutant plasmids were co-transfected with Top/Fop flash reporters (Millipore, Germany) and the pRL plasmid as an internal reference (ratio of 3:1:0.1). The cells were harvested after 24-48 h, washed twice with phosphate-buffered saline (PBS), lysed in lysis buffer (Promega, Madison, WI, USA), and centrifuged at $13,000 \mathrm{rpm}$ for $1 \mathrm{~min}$. The luciferase activities were measured in the lysate supernatants using the DualLuciferase Reporter Assay System (Promega).

\section{Co-Immunoprecipitation and western blot analysis}

For Co-IP studies, cells were harvested; incubated on ice for $15 \mathrm{~min}$ with $200 \mu \mathrm{l}$ of RIPA lysis buffer containing $1 \%$ NP-40, 0.25\% deoxycholic acid, $5 \mathrm{mM}$ Dithiothreitol (DTT), and $1 \times$ protease inhibitor cocktail (Merck, NJ, USA); and centrifuged for $10 \mathrm{~min}$ at $13,000 \mathrm{rpm}$. The supernatants were collected and incubated with $5 \mu \mathrm{g}$ of primary antibody for $2 \mathrm{~h}$ at $4{ }^{\circ} \mathrm{C}$, then incubated overnight at $4{ }^{\circ} \mathrm{C}$ with $50 \mu \mathrm{l}$ protein $\mathrm{A} / \mathrm{G}$-Agarose beads (Santa Cruz Biotechnology, Santa Cruz, CA, USA), and centrifuged at 13,000 rpm for $10 \mathrm{~min}$. The beads were washed with lysis buffer and centrifuged 5 times. Subsequently, $50 \mu \mathrm{l}$ of loading buffer was added to the beads and the samples were heated for $3 \mathrm{~min}$ in a water bath at $100{ }^{\circ} \mathrm{C}$, cooled to room temperature (RT), and centrifuged for $1 \mathrm{~min}$ at 13,000 rpm. The resulting supernatants were collected for western blot analysis.

For western blot analysis, the cells were harvested and incubated on ice for $15 \mathrm{~min}$ with $200 \mu \mathrm{l}$ of RIPA lysis buffer containing 1\% NP-40, 0.25\% deoxycholic acid, $5 \mathrm{mM}$ DTT, and $1 \times$ protease inhibitor cocktail (Merck, NJ, USA). The lysates were centrifuged for $10 \mathrm{~min}$ at $13,000 \mathrm{rpm}$, and the supernatants were collected. The samples were mixed with $2 \times$ loading buffer, heated for $3 \mathrm{~min}$ in a $100{ }^{\circ} \mathrm{C}$ water bath, cooled to RT, and subjected to SDS-PAGE. The proteins were then transferred to a nitrocellulose membrane (Whatman, Dassel, Germany), blocked for $1 \mathrm{~h}$ at RT with Tris-base buffer saline $+0.05 \%$ Tween 20 (TBST) buffer containing 5\% skim milk, and then incubated with a primary antibody for $1 \mathrm{~h}$ at RT or overnight at $4{ }^{\circ} \mathrm{C}$. Primary antibodies against the following target proteins were used in this study: NRIP2, HBP1 (1:1,000; Novus, USA), cyclin D1, c-Myc, RAR $\alpha, \operatorname{ROR} \beta$ 
(1:1000-2000; Epitomics, CA, USA), and GAPDH (1:5000; KangChen Biotech, Shanghai, China). The nitrocellulose membrane was washed with TBST and then incubated with a secondary antibody (HRP-labeled goat anti-rabbit antibody or HRP-labeled goat anti-mouse antibody, 1:2000, Cell Signaling Technology, Danvers, MA, USA) for $1 \mathrm{~h}$ at RT. Bands were visualized by exposing the membranes to ECL reagent (Cell Signaling Technology).

\section{Immunohistochemical staining}

Following approval by the Ethics Committee of The Second Affiliated Hospital of the Zhejiang University School of Medicine, histological sections of colorectal cancer tissues were incubated overnight at $60{ }^{\circ} \mathrm{C}$, fully hydrated with xylene and gradient alcohol, placed in antigen retrieval solution ( $\mathrm{pH}$ 8.0, $100 \mathrm{mM}$ EDTA), and heated for 15 min. Subsequently, the sections were cooled to RT, washed 3 times in TBST, blocked for $20 \mathrm{~min}$ at RT with TBST containing $10 \%$ goat serum, and washed 3 times in TBST. Sections were incubated overnight at $4{ }^{\circ} \mathrm{C}$ with an anti-NRIP2 antibody (1:1000, Novus, CO, USA), an antiROR $\beta$ antibody (1:250, Novus, USA). After incubation with the primary antibody, the sections were washed 3 times in TBST and incubated for $1 \mathrm{~h}$ at RT with a secondary rabbit antibody (1:200; Dako, Denmark). The sections were developed with 3,3'-diaminobenzidine, counterstained with hematoxylin, and examined by microscopy.

\section{Lentivirus infection}

For NRIP2 or ROR $\beta$ over-expression, colorectal cancer cells were infected for $24 \mathrm{~h}$ with recombinant lentivirus encoding human NRIP2 or RORB (Shanghai Innovation Biotechnology Co. for NRIP2 and Shanghai Ruisai Biotechnology Co. for $R O R B)$; meanwhile, the cells were infected with blank vector lentivirus as a control. For target gene knockdown, colorectal cancer cells were infected for $72 \mathrm{~h}$ with lentivirus encoding shRNAs against NRIP2, RORB, or HBP1 or with scrambled shRNA as a control (Santa Cruz Biotechnology). Subsequently, cells were selected in puromycin $(5 \mu \mathrm{g} / \mathrm{ml})$ for 2 weeks. Clonal cells stably expressing shRNAs were cultured by limiting dilution, and the efficiency of target gene knockdown was verified by western blot analysis.

\section{Construction of NRIP2 and RORB plasmids}

The NRIP2 ORF DNA sequence (Genbank access: AL136557) was synthesized by the Shanghai Xuguan Biotechnology Development Co. Ltd. and cloned into the pUC57 vector (Thermoscientific, MA USA). The RORB/ pReceiver plasmid was purchased from Fulengen Co. Ltd (Guangzhou, China). Subsequently, the NRIP2 and RORB ORF DNA sequences were subcloned into the $p E G F P-C 1$ vector at the XhoI and BamHI sites, respectively. Constructs were confirmed by DNA sequencing.

\section{RT-PCR and RT-qPCR}

Total RNA was extracted from cells receiving different treatments using a RNA mini kit (Qiagen, Germany). After the quantity of RNA was checked, the RNA was reversed transcribed to cDNA by PrimeScript ${ }^{\mathrm{Tm}}$ reverse transcriptase with a gDNA eraser kit (Takara, Japan). RT-PCR and Taqman RT-qPCR were carried out using the Premix EX Taq ${ }^{\text {TM }}$ hot start version PCR and Perfect Real Time PCR kits following the manufacturer's instructions. The primers used are as below: NRIP2: $5^{\prime}$ cacaggcacccaatacaatc-3'(Forward), 5'-tgtagctccaactgct c cac-3' (Reverse), 5'Fam-ccaggcggctgagacatcca-3'Tamra (Probe); RORB: 5' -gcttcttattcctgcccaag-3'(Forward), 5' cttggacatcctcccaaact-3'(Reverse), 5' Fam-aaccgttgccaaca ctgccg-3'Tamra (Probe); GAPDH: 5'-atcatcctgcc tct actgg-3' (Forward), 5' -gtcaggtccaccactgacac-3'(Reverse), 5'Fam-accttgc ccacagccttggc-3' Tamra (Probe).

\section{Gene chip detection}

SGC7901 cells were transiently transfected with $R O R B /$ pReceiver plasmids (Fulengen) using Lipofectamine 2000 reagent (Invitrogen, USA) for $48 \mathrm{~h}$. The cells were lysed by the addition of $1 \mathrm{~mL}$ of Trizol reagent (BBI, Canada), and total RNA was extracted. A GeneChip ${ }^{\circ}$ PrimeView $^{\text {Tm }}$ Human Gene Expression Array (Affymetrix, USA) was used to detect global mRNA expression profiles. Differences in mRNA expression were verified by RT-qPCR.

\section{Chromatin immunoprecipitation}

A commercial kit (Upstate, Millipore, USA) was used to perform ChIP assays according to the manufacturer's instructions. In brief, SGC7901 cells were seeded in a 100$\mathrm{mm}$ dish at $70 \%$ confluency overnight and subsequently transiently transfected with $R O R B /$ pReceiver plasmids for an additional $48 \mathrm{~h}$. Transfected cells were fixed by a final concentration of $1 \%$ formaldehyde for $10 \mathrm{~min}$; the reaction was terminated by adding $0.5 \mathrm{~mL}$ of $1 \mathrm{M}$ glycine solution. The cells were collected and lysed by SDS reagent. The DNA fragments were co-immunoprecipitated by anti-myc tag antibodies in agarose at $4{ }^{\circ} \mathrm{C}$ overnight after sonication. The immunoprecipitated DNA fragments were purified and eluted by the spin filter method. PCR was used for the detection of the HBP1 upstream DNA fragments with the primers: Forward:5'-gtcctttgcaggacatggat-3, Reverse: 5'-gtgccatggaggtttgctat-3'. Blank, normal mouse IgG was used as a negative control, and anti-RNA polymerase II was used as a positive control.

\section{EMSA}

An Electrophoretic Mobility Shift Assay (EMSA) kit (Pierce, Thermo Scientific, USA) was used to perform EMSA assays according to the manufacturer's instructions. DNA sequences of the wild-type and mutant hormone response elements were chemically synthesized. Upstream 
and downstream DNA primers $(100 \mu \mathrm{M})$ were mixed and incubated at $94{ }^{\circ} \mathrm{C}$ in vitro for $5 \mathrm{~min}$ and allowed to cool to $\mathrm{RT}$. The probe was incubated with recombinant ROR $\beta$ for 30 min and resolved on a 6\% PAGE gel. The DNA was then transferred to a nylon membrane and crosslinked for $1 \mathrm{~min}$, after which HRP-labeled streptavidin was added for $30 \mathrm{~min}$ and an enhanced ECL reagent was used for detection. WT: 5'-Bio-gatcacgaggtcaagagatcgagaccatcctg-3'(Forward), 5'-Bio-caggatggtctcgatctcttgacctcgtgatc-3' (Reverse); Mut1:5'-Bio-gatcacg aggtcaagaccatcctg-3' (Forward), 5'-Biocaggatggtcttgacctcgtgatc-3' (Reverse); Mut2: 5'-Bio-gatcacgaggtcaagagatcgtcctg-3' (Forward), 5'-Bio-caggacgatct cttga cctcgtgatc-3' (Reverse); Mut3: 5'-Bio-gatcacgagagatcgagaccatcctg -3' (Forward), 5'-Bio-caggatggtctcgatctctcgtgatc-3' (Reverse).

\section{Construction and transfection of the HBP1 promoter/ pGL3 luciferase reporter vector}

Bioinformatics analysis of the human $H B P 15^{\prime}$ flanking region was used to design the following PCR primers: 5' -agtcactgagctctgtcccagacaccaaaacaa-3' (forward) and 5'-agtcactctcgagcggcagctcttactcctcaa-3' (reverse). DNA from SW620 cells was used as a template. The $\sim 2,500 \mathrm{bp}$ promoter region of the $H B P 1$ gene was amplified using 35 cycles of $95{ }^{\circ} \mathrm{C}$ for $10 \mathrm{~s}, 55{ }^{\circ} \mathrm{C}$ for $15 \mathrm{~s}$, and $72{ }^{\circ} \mathrm{C}$ for $150 \mathrm{~s}$. The PCR product was doubly digested with XhoI and SacI enzymes and inserted into the pGL3-basic vector (Promega), creating a luciferase reporter gene vector containing the $H B P 1$ promoter region (pGL3-HBP1). The primers used to construct the $H B P 1$ gene promoter reporter vector containing hormone response elements were as follows: $5^{\prime}$-agtcactctcgagcggcagctcttactcctcaa-3' (forward) and 5 '-agtcactgagc tcggaggatcacgaggtcaagagat cgagaccatcctggtgtcccagacaccaaaacaa-3' (reverse). Plasmid DNA containing the $H B P 1$ promoter was used as a template for PCR, with 10 cycles of $\left(95^{\circ} \mathrm{C}\right.$ for $10 \mathrm{~s}, 58.8^{\circ} \mathrm{C}$ for $15 \mathrm{~s}$, and $72{ }^{\circ} \mathrm{C}$ for $\left.40 \mathrm{~s}\right)$ and 20 cycles of $\left(95^{\circ} \mathrm{C}\right.$ for $10 \mathrm{~s}$, $69.0{ }^{\circ} \mathrm{C}$ for $15 \mathrm{~s}$, and $72{ }^{\circ} \mathrm{C}$ for $40 \mathrm{~s}$ ). The PCR product was doubly digested with XhoI and SacI enzymes and inserted into the pGL3-basic vector, creating a $H B P 1$ promoter reporter vector containing hormone response elements.

The pGL3-HBP1, RORB-pCMV6/XL4, and pRL plasmids (an internal reference) were co-transfected (1:3:0.1) by Lipofectamine 2000 reagent into SGC7901 tumor cells for $24 \mathrm{~h}$. The cells were collected and washed twice in $0.01 \mathrm{M}$ PBS (pH7.4) and lysed in lysis buffer (Promega, Madison, WI, USA). The cell lysates were centrifuged at 13,000 rpm for $1 \mathrm{~min}$, and the supernatants were collected for the measurement of luciferase activity. The pGL3-basic, pCMV6/XL4, and pRL plasmids were co-transfected (1:3:0.1) in control experiments.

\section{Statistical analysis}

Continuous variables were expressed as the mean \pm standard deviation (SD). Single factor analysis of variance and $t$ tests were used to compare multiple groups of independent samples or paired samples. The level of significance was set as $p<0.05$. Statistical analysis was performed using SPSS 18 (SPSS Inc., Chicago, IL, USA).

\section{Results}

Wnt activity is important for the self-renewal of CCICs

To evaluate the effect of Wnt activity on CCIC selfrenewal, we first enriched colospheres in vitro from primary colorectal cancer tissues and colorectal cancer cell lines and identified their stem-like properties. Using serum-free, low-adhesion culture conditions, colospheres were successfully enriched and dilute passaged from 3 primary colorectal cancer cells as well as colorectal cancerderived HT29 and SW620 cells. Furthermore, single cells from these spheres were able to form organoids in the conditioned Matrigel medium (Fig. 1a). These colospheres were inoculated into NOD/SCID mice, and they exhibited significantly increased tumorigenicity (Fig. 1b). These results suggested that the enriched colospheres possessed cancer-initiating cell properties. Next, we assayed for Wnt activity in the colosphere cells. Both Top/Fop flash reporter assays and western blots indicated that these colosphere cells had relatively strong Wnt activity compared with their parental cells (Fig. 1c and d). Finally, we evaluated the effect of Wnt pathway activation on the selfrenewal capacity of CCICs. The number of colospheres was obviously increased after Wnt signaling was activated by the addition of recombinant Wnt3a (Fig. 1e). However, the number of colospheres significantly decreased in primary colorectal cancer P1, HT-29, and SW620 cells after CTNNB1 was knocked down by RNA interference (Fig. 1f). Treatment with Wnt and $\beta$-catenin chemical inhibitors showed similar results (Fig. 1g). Collectively, these results suggested that activation of the Wnt pathway plays an important role in the self-renewal capacity of CCICs.

\section{NRIP2 is significantly up-regulated in CCICs}

The above results demonstrated that Wnt pathway activation plays an important role in maintaining the self-renewal of CCICs; however, the molecular mechanisms whereby Wnt pathway activation occurs in CCICs remain unclear. To screen molecular activators of the Wnt pathway, we constructed a retroviral cDNA library from SW620 colosphere cells and screened it by colosphere formation and Top/Fop flash reporter assays as well as DNA sequencing (Fig. 2a). Based on these screening strategies, there were 13 candidates from SW620 colosphere cells identified by DNA sequencing (Additional file 1 : Figure S2a). We found that among these candidates, 
A

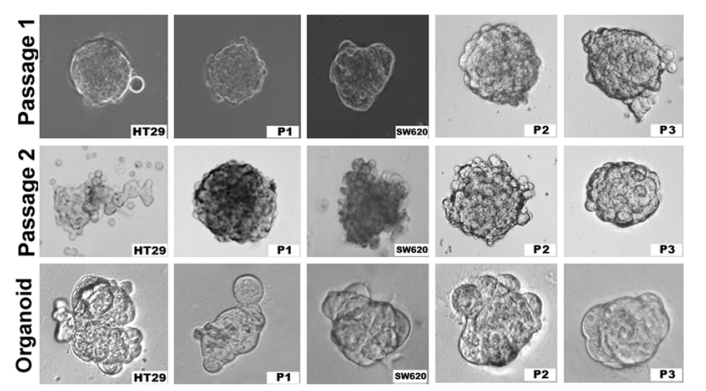

B

\begin{tabular}{ccc} 
& \multicolumn{3}{c}{ Tumorigenesis in vivo } \\
\cline { 2 - 3 } cells & Colosphere* & Parental Control \\
\hline 1000 & $3 / 9$ & $0 / 9$ \\
5000 & $7 / 9$ & $2 / 9$ \\
10000 & $9 / 9$ & $6 / 9$ \\
\hline
\end{tabular}

C.

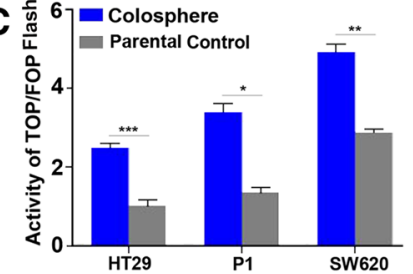

D

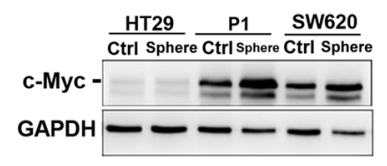

E

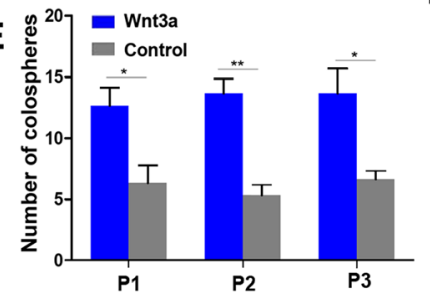

$\mathbf{F}$

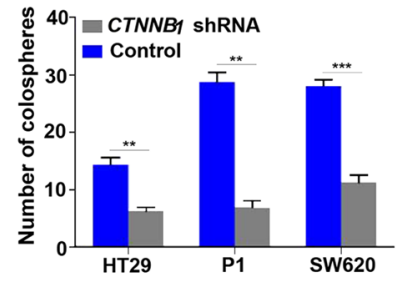

G

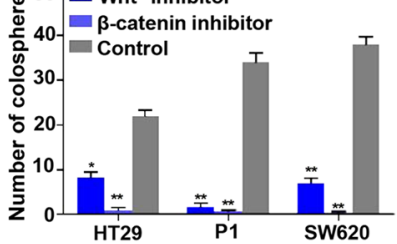

Fig. 1 Wnt activity is important for the self-renewal of CCICs. a Colospheres were enriched from 3 primary colorectal cancer tissues, colorectal cancer HT29 cells, and SW620 cells on the 5th day in low-adhesive and serum-free culture medium. Colosphere formation occurred after the serial dilution of cells on the 5th day. Single colosphere cells formed organoids in growth factor-deficient Matrigel medium at the 5-7th day (bottom). b Tumorigenicity of colospheres. Different numbers of colosphere cells from primary colorectal cancer tissues (P1 cells) were injected into NOD/SCID mice and tumor formation was quantified after 8 weeks. The results showed that colospheres exhibited significantly increased tumorigenicity $(p<0.05$, Multivariate logistic analysis). The same number of parental cells was used as a control. c Wnt activity in colospheres. Colosphere or parental cells (control) were transfected with Top/Fop flash reporters, and the Wnt pathway activity was determined at $24 \mathrm{~h}$ post-transfection. The fold-change was calculated relative to controls. The values are represented as the mean \pm SD from triplicate samples. ${ }^{*} p<0.05 ;{ }^{* *} p<0.01 ;{ }^{* *} p<0.001$ (ANOVA). $\mathbf{d}$ The levels of Wnt signaling downstream of c-Myc were detected by western blotting in HT29, P1 and SW620 colospheres (Spheres), with their parental cells as controls. e Quantification of organoid formation after Wnt pathway activation. The number of organoids was counted from 3 primary colorectal cancer cells (100 cells/well) by the treatment of recombinant Wnt3a $(200 \mathrm{ng} / \mathrm{mL})$ for 7 days; cells without treatment of Wnt3a were used as controls. The number of organoids significantly increased after Wht pathway activation. ${ }^{*} p<0.05$ (ANOVA). f Quantification of colosphere formation after CTNNB1 knockdown. The colosphere number was counted in CTNNB1-knockdown HT29, P1, and SW620 cells under low-adhesive and serum-free conditions for 7 days. The colosphere number significantly decreased in these cells after knockdown of CTNNB1. ${ }^{* *} p<0.01 ;{ }^{* * *} p<0.001$ (ANOVA). g Quantification of colosphere formation after Wnt pathway inactivation. Colospheres were counted in HT29, P1, and SW620 cells treated with Wnt inhibitor (7.2 $\mu$ M) or $\beta$-catenin inhibitor $(3.6 \mu \mathrm{M})$ for 7 days, with the solvent dimethyl sulphoxide (DMSO) as a control. The colosphere number significantly decreased after the inhibition of Wnt activity. ${ }^{*} p<0.05$; ${ }^{* *} p<0.01$; (ANOVA)

only the function of NRIP2 was undefined for promoting the self-renewal of colosphere cells.

Western blot analysis showed that NRIP2 was expressed in primary colorectal P1, HT29, and SW620 cells (Fig. 2b, Additional file 1: Figure S2b). The presence of NRIP2 in primary tumor cells was confirmed by mRNA fluorescence in situ hybridization (FISH) and immunohistochemical (IHC) staining (Fig. 2c and d). To verify that NRIP2 is expressed at a higher level in CCICs, we isolated $\mathrm{CD} 44^{+} \mathrm{CD} 24^{+}$colorectal cancerinitiating cells from primary colorectal P1 and SW620 cells by fluorescence-activated cell sorting (FACS) and colospheres from colorectal cancer cell lines and primary colorectal cancer tissues. RT-qPCR analysis showed that NRIP2 expression was significantly higher in $\mathrm{CD} 44^{+} \mathrm{CD} 24^{+}$ cells and colosphere cells (Fig. 2e-g). Similar results were observed in $\mathrm{CD}_{133^{+}}$and Aldefluor ${ }^{+}$colorectal cells (Additional file 1: Figure S2c and S2d). On the other hand, we analyzed the relationship between NRIP2 expression and colorectal cancer molecular typing in 565 cases of colorectal cancer from a global cDNA expression genechip database and found that high NRIP2 expression was closely related to the C4-cancer stem cell (CSC) subtype of colorectal cancer (Fig. 2h) [29]. Gene set enrichment analysis (GSEA) also showed that in colorectal cancer cells expressing high levels 
A

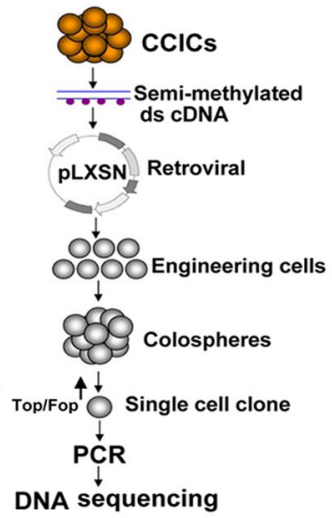

B

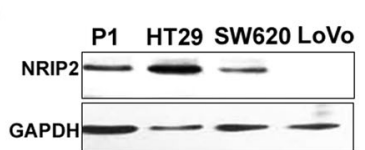

C

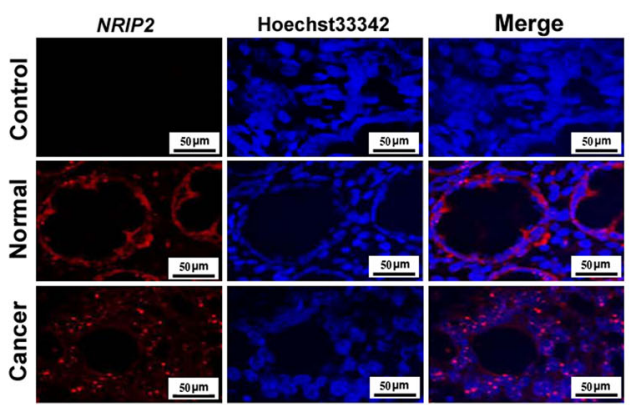

D

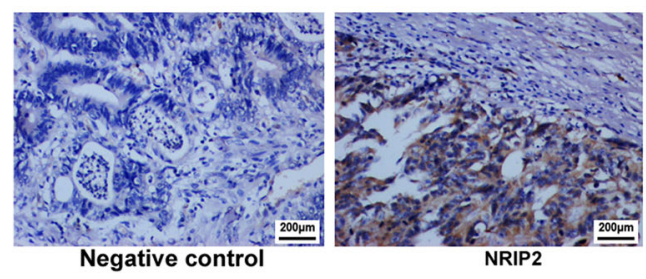

E
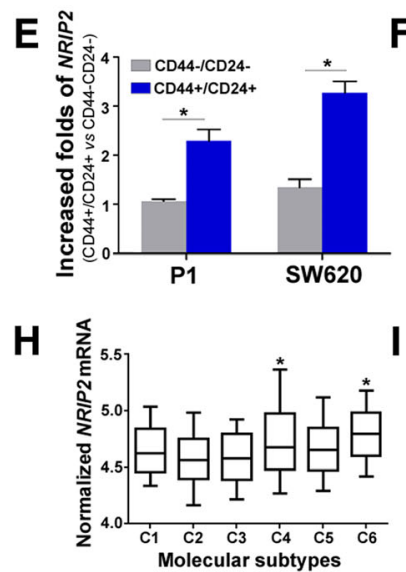
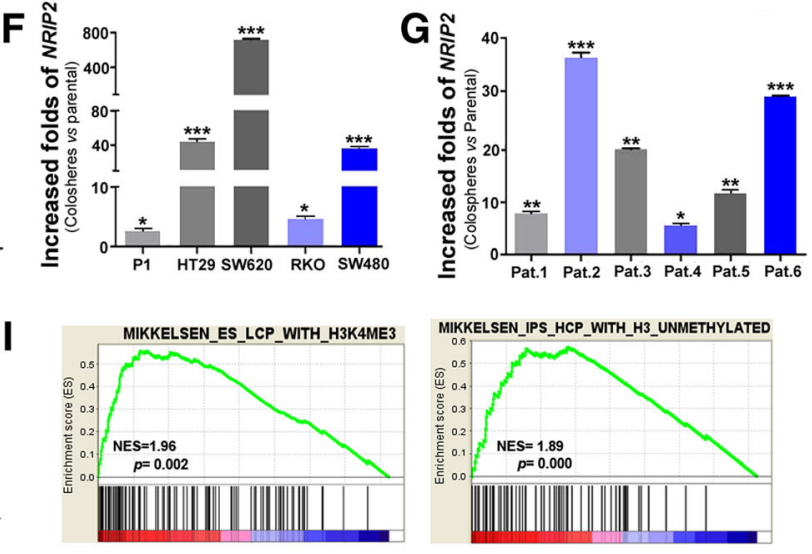

Fig. 2 NRIP2 is significantly upregulated in CCICs. a Screening strategy for NRIP2. NRIP2 was identified in a screen for colosphere formation using a retroviral cDNA expression library constructed from SW620 colosphere RNA (as detailed in the Materials and Methods). b NRIP2 expression in colorectal cancer cells. NRIP2 was detected by western blotting in colorectal cancer cells. The results showed that P1, HT29, and SW620 cells expressed NRIP2. c NRIP2 mRNA hybridization. Slides containing primary colorectal cancer tissue and normal colorectal tissue were hybridized with labeled probes for NRIP2 mRNA respectively, with a nonsense probe as a negative control. FISH analysis showed NRIP2 expression in primary colorectal cancer cells. $\mathbf{d}$ Expression of NRIP2 in primary colorectal cancer tissue. Colorectal cancer cells were reacted with antibodies against NRIP2 and subsequently detected by IHC staining. Normal rabbit IgG was used as a negative control. e NRIP2 increased in CD44+CD24+ cancer cells. NRIP2 mRNA levels were determined by Taqman RT-qPCR in CD44 + CD24+ and CD44-CD24- FACS-isolated cells. NRIP2 expression increased in CD44 + CD24+ cells compared with CD44-CD24- cells; ${ }^{*} p<0.05$ (ANOVA). f NRIP2 expression in colospheres from colorectal cancer cells. NRIP2 levels were determined by Taqman RT-qPCR in colospheres from P1, HT29, RKO, and SW620 cells under low-adhesive and serum-free conditions for 7 days. NRIP2 mRNA expression was significantly higher in colospheres than in parental cells. ${ }^{*} p<0.05 ;{ }^{* *} p<0.001$ (ANOVA). $\mathbf{g}$ NRIP2 expression in colospheres from primary colorectal cancer cells. NRIP2 levels were determined by Taqman RT-qPCR in colospheres from primary colorectal cancer samples under low-adhesive and serum-free conditions for 7 days. NRIP2 mRNA expression was significantly higher in colospheres than in their parental cells. ${ }^{*} p<0.05 ;{ }^{* *} p<0.01$; ${ }^{* * *} p<0.001$ (ANOVA). $\mathbf{h}$ Analysis of the relationship between NRIP2 and the colorectal cancer subtypes. The relationship between NRIP2 expression and colorectal cancer molecular typing was analyzed by the global cDNA expression GeneChip database $(n=565)$. NRIP2 expression was closely related to the C4-cancer stem cell (CSC) and C6-CIN colorectal cancer subtypes. C4 vs C2 or C3, all $p<0.05$; C4 vs C2 or C3, all $p<0.01$. i GSEA analysis. GSEA analysis from primary colorectal cancer tissues with a high level of NRIP2 expression $(n=200)$. Similar alterations in the mRNA expression profiles were found in cases with high levels of NRIP2 expression and in ES cells with histone methylation or iPS cells without histone methylation

of NRIP2, the alteration of the mRNA expression profiles was similar to that observed with low- and intermediate-CpG-density promoters bearing the histone $\mathrm{H} 3$ trimethylation marker at K4 and K27 (H3K4me3 and H3K27me3) in embryonic stem cells (ES) and induced pluripotent cells (iPS) (Fig. 2i).
These results suggested that NRIP2 may play an important role in the self-renewal of CCICs.

\section{NRIP2 up-regulates Wnt pathway activity}

To characterize the relationship between NRIP2 and Wnt activity, we determined the impact of NRIP2 on 
Wnt activity in HT29, P1 and SW620 cells. Western blots showed that the Wnt pathway downstream targets were significantly increased in cells after overexpression of NRIP2, while it was obviously decreased after silencing of NRIP2 in these cells (Fig. 3a and b, Additional file 1: Figure S3). Furthermore, the colosphere numbers were significantly attenuated in NRIP2- overexpressing HT29 and P1 cells after silencing of NRIP2 (Fig. 3c). Finally, we evaluated whether NRIP2 promoted the self-renewal of CCICs dependent on Wnt activation. To this end, we observed a change in the colosphere number in NRIP2overexpressing cells after inactivation of Wnt. The results showed that NRIP2 overexpression did not reverse the inhibition caused by Wnt- and $\beta$-catenin chemical inhibitors (Fig. 3d). NRIP2 overexpressing cells were inoculated into NOD/SCID mice, and they exhibited significantly increased tumorigenicity (Fig. 3e). Together, these findings suggested that NRIP2 involves in the self-renewal of colorectal cancer cells by activating the Wnt pathway.

NRIP2 regulates the activity of the Wnt pathway via ROR $\beta$ To discover downstream target molecules by which NRIP2 regulates the Wnt pathway, we performed a literature review and target prediction (www.genecards. org) and found that NRIP2 can interact with ROR $\beta$ [30]. Thus, we performed Co-IP and western blot analysis with cells overexpressing NRIP2 and ROR $\beta$. The results confirmed that both exogenous and endogenous NRIP2 could be co-immunoprecipitated with ROR $\beta$ (Fig. 4a and $b$ ), but NRIP2 could not bind to RAR $\alpha$ (Additional file 1: Figure S4). These results suggest that NRIP2 may be involved in the Wnt pathway.

Although NRIP2 can interact with ROR $\beta$, it is not clear whether ROR $\beta$ affects Wnt pathway activity. Therefore, we transiently expressed ROR $\beta$ in SGC7901 cells, which had the highest transfection efficiency. The results from Top/Fop flash assays and western blots showed that the activity of the Wnt pathway was significantly inhibited by ROR $\beta$ overexpression (Fig. 4c and d). To determine whether NRIP2 activates the Wnt pathway dependent on ROR $\beta$, we established RORB-knockdown cells and checked the effect of NRIP2 on these cells. The results showed that NRIP2 could not activate the Wnt pathway after knockdown of RORB (Fig. 4e and f). Together, these results suggested that ROR $\beta$ is an inhibitor of the Wnt pathway and that NRIP2 may affect Wnt pathway activity via ROR $\beta$.

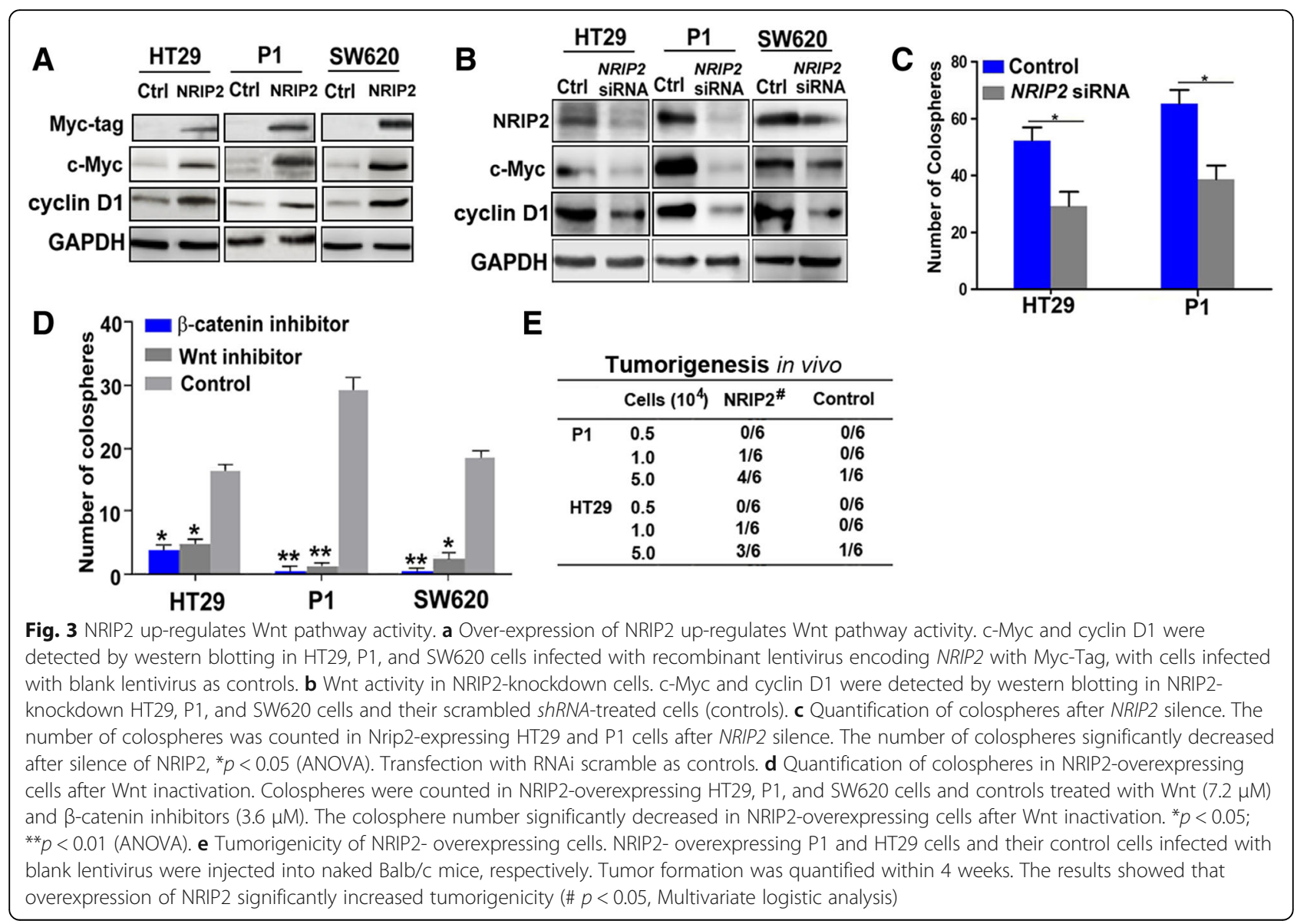



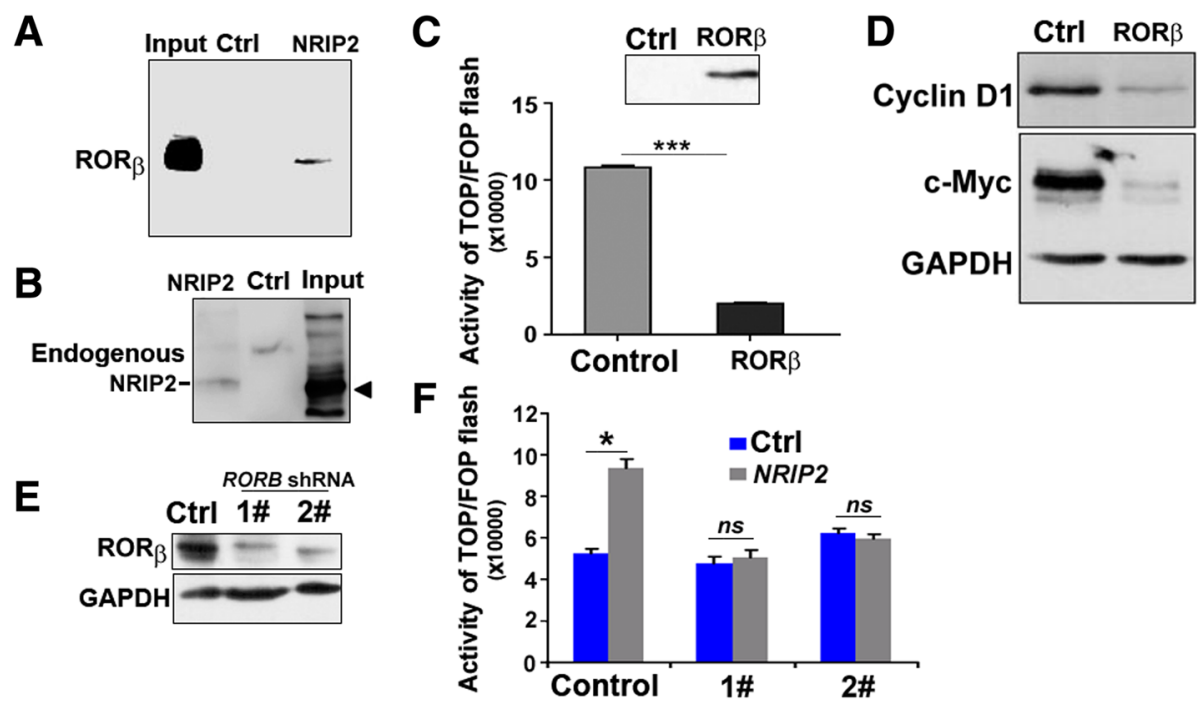

Fig. 4 NRIP2 regulates the activity of the Wnt pathway via RORß. a Analysis of NRIP2 binding to RORß. Lysates from NRIP2-overexpressing SGC cancer cells or control cells were subjected to co-IP with myc-tag antibody agarose beads, followed by western blotting with anti-ROR $\beta$ antibodies. Normal rabbit lgG agarose beads were used as a negative control. $\mathbf{b}$ Endogenous NRIP2 interacts with RORß. Lysates from P1 cells without treatment with protease inhibitor cocktails were subjected to co-immunoprecipitation with RORß antibodies or mouse lgG (control), followed by western blotting with anti-NRIP2 antibodies. Normal rabbit lgG agarose beads were used as a negative control. c Wnt activity in RORß-expressing cells. Wnt activity was assessed by Top/Fop flash reporter assays in SGC7901 cells $24 \mathrm{~h}$ after transient transfection with RORB or control plasmids. Overexpression of ROR $\beta$ attenuated Wnt activity. ${ }^{*} p<0.05$ (ANOVA). $\mathbf{d}$ Detection of Wnt dowmstream targets in RORß-expressing cells. c-Myc and cyclin D1 were detected by western blotting in the above ROR $\beta$-overexpressing SGC7901 and control cells. e Detection of RORß in RORB-knockdown cells. Cells were infected with lentivirus encoding RORB shRNA for $72 \mathrm{~h}$ and subsequently screened with $5 \mu \mathrm{g} / \mathrm{mL}$ Puromycin for 7 days. The surviving cell clone was picked out with limiting dilution analyses. ROR $\beta$ was detected by western blotting in these RORB-knockdown clones, with cells infected with scrambled shRNA lentivirus as controls. $\mathbf{f}$ NRIP2 failed to activate the Wnt pathway in RORB-knockdown cells. Wnt activity was assessed by Top/Fop flash reporter assays in RORB-knockdown SGC7901 cell clones $24 \mathrm{~h}$ after transient transfection with NRIP2 or control plasmids. NRIP2 could not activate the Wnt pathway after knockdown of $R O R B .{ }^{*} p<0.05$ (ANOVA), ns: non-significance, $p>0.05$ (ANOVA)

\section{ROR $\beta$ inhibits tumorigenesis and the self-renewal of CCICs}

Previous studies have demonstrated that $R O R \beta$ is mainly distributed in the central nervous system [31, 32], however, whether ROR $\beta$ is also expressed in intestinal epithelial cells is unverified. To confirm that $\operatorname{ROR} \beta$ is expressed in intestinal epithelial tissue, we evaluated ROR $\beta$ expression in colorectal cancer cells by RT-qPCR and western blotting. Immunostaining of ROR $\beta$ was also carried out in human primary colorectal cancer tissues. We also examined $R O R B$ mRNA expression in primary colorectal cancer tissues by RT-qPCR and mRNA FISH. We found that $R O R B$ was expressed in colorectal cancer cells, but at a lower level in colorectal cancer tissue than in matched para-carcinoma tissues (Fig. 5a-c, Additional file 1: Figure S5). The level of RORB in CCICs was not significantly different from their parental cells (data not shown). To further clarify the effect of ROR $\beta$ on CCICs, we observed the tumorigenicity in vivo, the change in the colosphere number and the ratios of CD44+CD24+ cancer-initiating cells in cells with overexpression of ROR $\beta$. The results showed that the tumorigenic capacity was significantly reduced (Fig. $5 \mathrm{~d}$ ), the sphere-forming efficiency was decreased and the ratio of $\mathrm{CD} 44^{+} \mathrm{CD} 24^{+}$cells and the number of colospheres were also obviously reduced in colorectal cancer cells after overexpression of ROR $\beta$ (Fig. 5e and f). Inversely, RORB knockdown led to increased colosphere formation (Fig. $5 \mathrm{~g}$ and h). These results suggested that ROR $\beta$ negatively regulates the selfrenewal of CCICs as a suppressor.

\section{HBP1 is a crucial target of ROR $\beta$ in regulation of the Wnt pathway}

To investigate how ROR $\beta$ inhibits Wnt activation, we first analyzed changes in mRNA expression in cells overexpressing ROR $\beta$. Genechip-scanning experiments showed that $H B P 1$, a protein that blocks TCF binding to DNA [33], was significantly increased in cells overexpressing ROR $\beta$ (Fig. 6a). This result was subsequently confirmed by western blot analysis (Fig. 6b). However, HBP1 obviously reduced following $R O R B$ silencing (Fig. 6c). Similiarly, HBP1 was also reduced in the CCICs and crypts of intestinal mucosa from Rorb $^{-/-}$mice (Additional file 1: Figures S6 and S7a). These results suggest that HBP1 is a downstream target of ROR $\beta$. Furthermore, Chromatin Immunoprecipitation (ChIP) experiments showed that ROR $\beta$ could bind to HBP1 upstream DNA sequences (Fig. 6d). Next, the upstream promoter region sequences of $H B P 1$ 

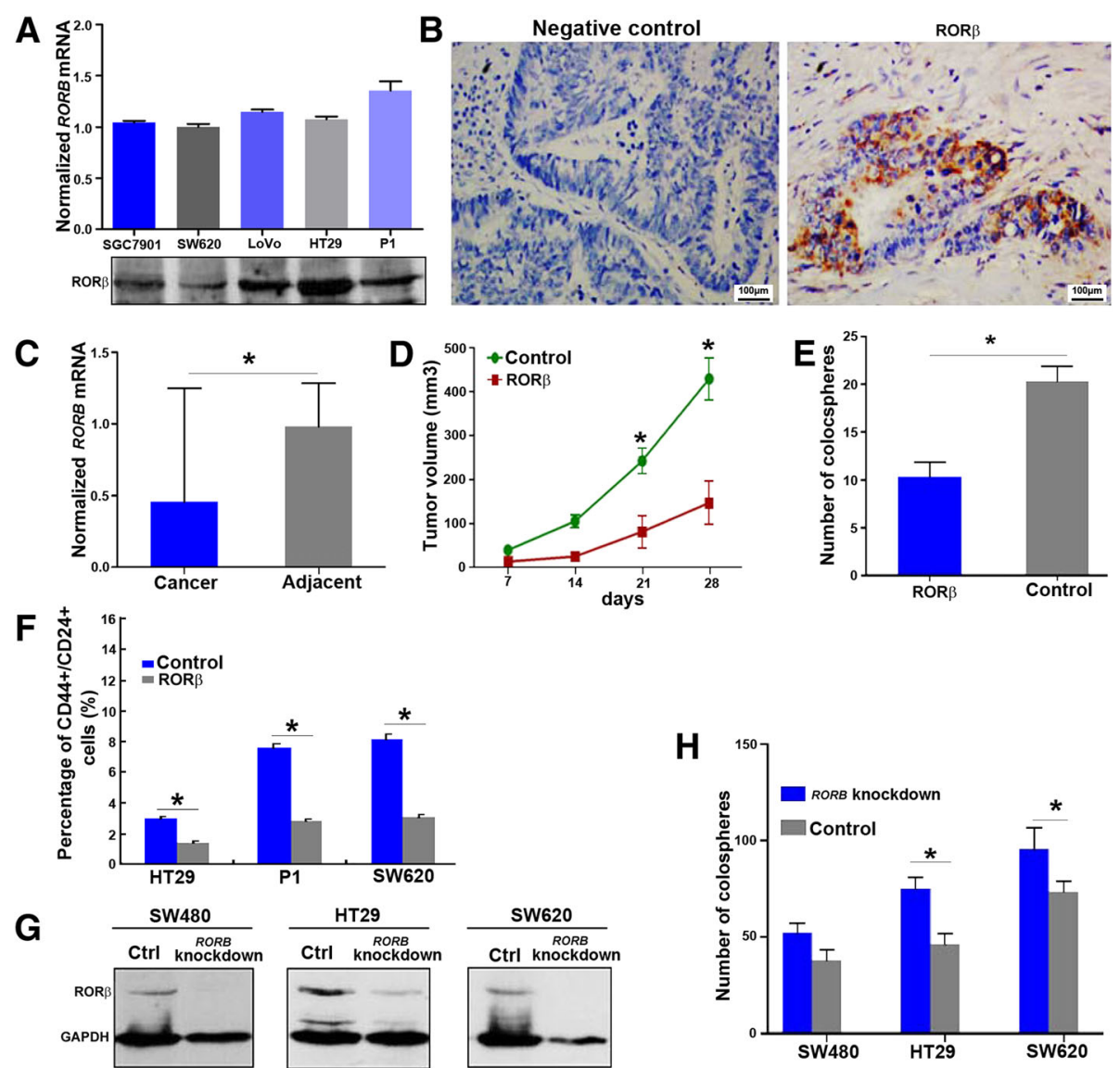

Fig. 5 RORB inhibits tumorigenesis and the self-renewal of CCICS. a RORB expression in colorectal cancer cells. RORB mRNA and protein expression levels were detected in colorectal cancer cells by Taqman RT-qPCR and western blotting, respectively. RORB mRNA was normalized with GAPDH. $\mathbf{b}$ ROR $\beta$ expression in primary colorectal cancer tissues. ROR $\beta$ expression in human primary colorectal cancer tissues was detected by IHC staining with antibodies against RORB. Normal rabbit lgG was used as a negative control. c RORB mRNA in primary colorectal cancer tissues. RORB mRNA was measured by Taqman RT-qPCR in 14 patients with colorectal cancer. The results showed that the levels of RORB in colorectal cancer cells were significantly lower than those in matched adjacent tissues. ${ }^{*} p<0.05$ (ANOVA). $\mathbf{d}$ Tumorigenicity of RORß-overexpressing cells. RORß- overexpressing SW620 cells $\left(1 \times 10^{6}\right)$ as well as their control cells infected with blank lentivirus were injected into naked Balb/c mice, respectively $(n=5)$. Tumor formation was quantified within 4 weeks. ${ }^{*} p<0.05$ (ANOVA). The results showed that ROR $\beta$ inhibited tumor growth. e Quantification of colospheres in RORß-overexpressing cells. Colospheres were counted in RORB-overexpressing P1 and control cells infected with blank lentivirus at the 5th day under low-adhesion and serum-free condition. The number of colospheres significantly decreased after ROR $\beta$ overexpression compared with the controls. ${ }^{*} p<0.05$ (ANOVA). $\mathbf{f}$ Determination of the percentage of CD44 + CD24+ cells after overexpression of ROR $\beta$. The percentage of CD44 + CD24+ cells were analyzed by FCM in RORß-overexpressing HT29, P1 and SW620 cells, with cells infected with blank lentivirus as controls. The results showed that ROR $\beta$ reduced the percentage of CD44 + CD24+ cells compared with the control cells, all $p<0.05$ (ANOVA). $\mathbf{g}$ ROR $\beta$ expression in RORB-knockdown cells. Cells were infected with lentivirus encoding RORB shRNA for $72 \mathrm{~h}$ and subsequently screened with $5 \mu \mathrm{g} / \mathrm{mL}$ Puromycin for 7 days. The surviving cell clone was picked out with limiting dilution analyses. RORß was detected by western blotting in these RORB-knockdown clones, with cells infected with scrambled shRNA lentivirus as controls. $\mathbf{h}$ Quantification of colospheres in RORB-knockdown cells. Colospheres from the above RORB-knockdown colorectal cancer cell clones were counted at day 5 under serum-free conditions. The number of colospheres was significantly higher in RORB-knockdown cells than in the control cells. ${ }^{*} p<0.05$ (ANOVA)

were analyzed, and several ROR $\beta$ binding sequences were identified (Additional file 1: Figure S7b), EMSA detection confirmed that the HRE sequence AGGTCA is essential for ROR $\beta$ binding to the $H B P 1$ promoter region (Fig. 6e). By co-transfecting a $R O R B$ plasmid and a reporter encoding luciferase under the control of the $H B P 1$ promoter region sequences, we found that ROR $\beta$ obviously enhanced downstream luciferase activity, while co-transfection with NRIP2 significantly weakened its transcription activity
(Fig. $6 \mathrm{f}$ and g). NRIP2 could not activate the Wnt activity in HBP1-silencing cells (Fig. 6h). Western blots revealed that the Wnt pathway was activated in $H B P 1$ knockdown cells (Fig. 6i and j). These HBP1 knockdown cells were inoculated into NOD/SCID mice, and they exhibited significantly increased tumorigenicity (Fig. 6k). The in vitro colosphere-formation potential was also enhanced in these cells (Fig. $6 \mathrm{l}$ and m). However, both Wnt activation and the number of colospheres decreased in cells with 
A Control RORP

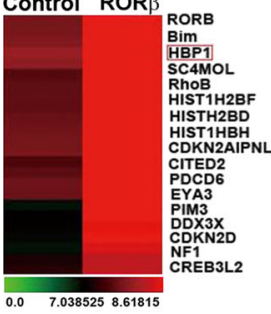

$\mathbf{F}$

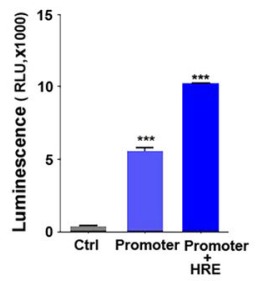

$\mathbf{J}$

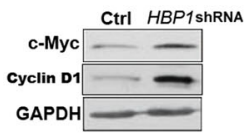

B

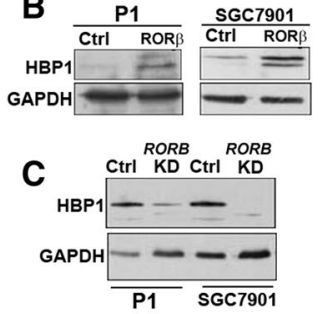

D

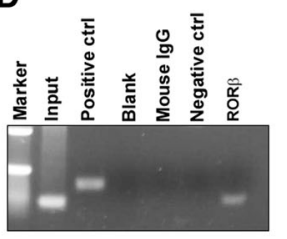

$\mathbf{E}$

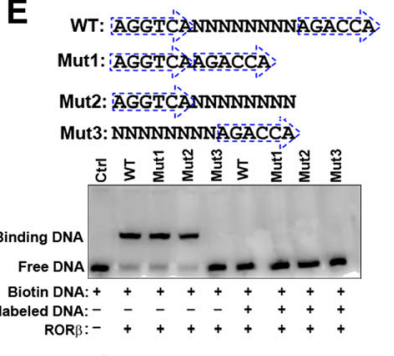

G

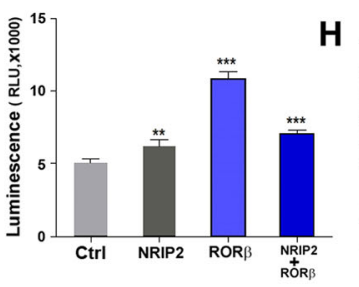

$\mathbf{K}$

\begin{tabular}{ccc}
\multicolumn{3}{c}{ Tumorigenesis in vivo } \\
\hline Cell number & HBP1 knockdown* & Control \\
\hline $5.0 \times 10^{4}$ & $5 / 5$ & $5 / 5$ \\
$1.0 \times 10^{4}$ & $5 / 5$ & $3 / 5$ \\
$0.5 \times 10^{4}$ & $1 / 5$ & $0 / 5$ \\
\hline
\end{tabular}

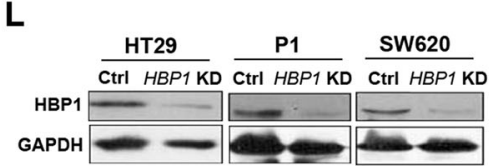

$\mathbf{L}$

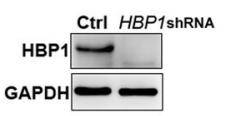

$\mathbf{N}$

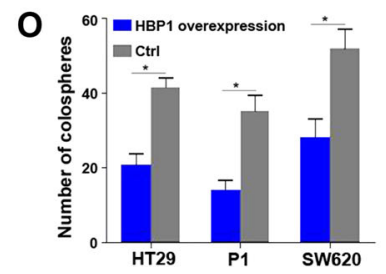

Fig. 6 HBP1 is a crucial target of RORß in regulation of the Wnt pathway. a Altered mRNA in RORß-overexpressing cells. SGC7901 cells were transiently transfected with $R O R B / p R e c e i v e r$ and control pReceiver plasmids for $24 \mathrm{~h}$. Total RNA was purified for global cDNA GeneChip scanning. The most significant up-regulated genes are listed. $\mathbf{b}$ Detection of HBP1 in ROR $\beta$-overexpressing cells. HBP1 was detected by western blotting in cells overexpressing ROR 3 . P1 cells infected with blank lentivirus and SGC7901 cells transfected with pReceiver plasmids were used as controls c Detection of HBP1 in RORB-knockdown cells. HBP1 was detected by western blotting in RORB-knockdown cells that were produced by infection with RORB shRNA lentivirus. HBP1 expression was significantly decreased after knockdown of RORB. P1 and SGC7901 cells infected with scrambled shRNA lentivirus were used as controls. $\mathbf{d}$ ChIP analysis of the interaction between ROR $\beta$ and HBP1 upstream DNA. DNA fragments were immunoprecipitated by anti-myc-tag antibodies agarose in ROR $\beta$ overexpressing SGC7901 cells after sonication. PCR was used for the detection of the HBP1 upstream DNA sequence. The results showed that ROR bound with the region upstream of HBP1 DNA. Blank, normal mouse lgG was used as a negative control, and anti-RNA polymerase II was used as a positive control. e ROR $\beta$ binds to hormone response elements (HRE) upstream of the HBP1 promoter region. An EMSA assay was used to identify the seed region for ROR $\beta$ binding within upstream hormone response elements of the HBP1 promoter region. Three mutants containing different potential binding sequences were constructed. The results showed that the hormone response element sequence AGGTCA is essential for ROR $\beta$ binding with the HBP1 promoter region. $\mathbf{f}$ HRE increased the activity of the promoter. Plasmids containing HRE or the promoter of HBP1 were co-transfected into 239 T cells for $24 \mathrm{~h}$. Luciferase activity was evaluated by the dual-luciferase reporter assay system. The results showed that HRE increased the HBP1 promoter activity, ${ }^{* * *} p<0.001$ (ANOVA). pRL3 plasmids were used as a control. $\mathbf{g}$ NRIP2 attenuated ROR 3 transactivation. The luciferase activity of the HBP1 promoter was determined in $293 \mathrm{~T}$ cells at $24 \mathrm{~h}$ after co-transfection of RORB and/or NRIP2 as well as in pRL3 plasmids containing HRE and the HBP1 promoter. The results showed that NRIP2 attenuated RORB transactivation, ${ }^{* * *} p<0.001$ (ANOVA). Blank pRL3 plasmids were used as a control. $\mathbf{h}$ NRIP2 could not activate Wnt activity in HBP1-silenced cells. Wht activity was evaluated by a luciferase activity assay in HBP1-silenced cells and scrambled P1 and SGC7901 cells (control) $24 \mathrm{~h}$ after co-transfection with Top/Fop flash reporters and NRIP2 plasmids. The results showed that NRIP2 could not activate Wnt activity in cells after silencing HBP1. ${ }^{* * *} p<0.001$ (ANOVA). i Detection of HBP1 in HBP1-knockdown cells. HBP1 was detected by western blotting in the SGC7901 cells with knockdown of HBP1 by shRNAs. SGC7901 cells transfected with scrambled shRNAs as a control. j Wnt activity in HBP1-knockdown cells. c-Myc and cyclin D1 were detected by western blotting in the above HBP1-knockdown and scrambled SGC7901 cells. k Tumorigenicity of HBP1-knockdown cells. HBP1-knockdown SGC7901 cells and their control cells infected with blank lentivirus were injected into naked Balb/c mice, respectively. Tumor formation was quantified within 4 weeks. The results showed that silence of HBP1 significantly increased tumorigenicity ( $p<0.05$, Multivariate logistic analysis). I HBP1 expression in HBP1-knockdown colorectal cancer cells. Colorectal cancer cells were infected with HBP1 shRNA lentivirus for knockdown of HBP1. HBP1 was detected by western blotting in these HBP1-knockdown and scrambled colorectal cancer cells (control). $\mathbf{m}$ Quantification of colospheres in HBP1-knockdown cells. Colospheres were counted in HBP1-knockdown and scrambled cells. The number of colospheres was significantly increased in HBP1-knockdown cells. ${ }^{* *} p<0.01$ (ANOVA). $\mathbf{n}$ Detection of the Wnt downstream targets in HBP1-overexpressing cells. c-Myc and cyclin D1 were analyzed by western blotting in HBP1-overexpressing and control (transfected with PCMV-XL4 plasmids) P1 cells. o Quantification of colospheres in HBP1-overexpressing cells. The number of colospheres was counted in the above HBP1-overexpressing and control cells. The results showed that HBP1 significantly inhibited colosphere formation. ${ }^{*} p<0.05$ (ANOVA) 
reinforced $H B P 1$ expression (Fig. 6n and o). In summary, these data suggested that the interactions between NRIP2, ROR $\beta$, and HBP1 regulated Wnt pathway activation and the self-renewal of CCICs.

\section{Discussion}

Using a retroviral library screening strategy, we demonstrated increased expression of NRIP2 in CCICs. NRIP2 was shown to be a novel interactor with the Wnt pathway. ROR $\beta$ was identified as a key target of NRIP2, through which NRIP2 regulates the activity of the Wnt pathway. The NRIP2-ROR $\beta$ interaction reduces $H B P 1$ transcription, thereby attenuating HBP1-dependent inhibition of the TCF4-DNA complex, finally promoting the self-renewal of CCICs by up-regulating Wnt pathways (Fig. 7).

NRIP2 belongs to the aspartic protease family [34]. Unlike other members of this family, such as Ddil, both the ubiquitin-associated domain and the ubiquitin-like binding domain are absent from the NRIP2 sequence, suggesting that NRIP2 has a different function from the other aspartic protease family members [35]. NIX1, a murine NRIP2 homolog, can bind directly to the $\mathrm{C}$-terminal ligandbinding domain (LBD) of mouse ROR $\beta$ independently of retinoic acid and thyroid hormone T3 to inhibit the transcriptional activity of ROR $\beta$. NIX1 was found to participate in transcriptional repression in yeast cells [30], but the mechanism whereby NRIP2 regulates the Wnt activity and the self-renewal of cancer initiating cells has been rarely reported.

Previously, $R O R B$ was primarily detected by Northern blotting, the expression of which was restricted to the central nervous system, in particular, to regions involved in modulating circadian rhythms, such as the suprachiasmatic nucleus, the pineal gland, and the retina $[31,32]$. Recently, ROR $\beta$ was detected in tissues outside of the nervous system, such as normal bone tissue, the endometrium and pancreatic cancer [36-38]. RORB, which had a high expression level in the endometrium in healthy preor post-menopausal women, was significantly downregulated in endometrial cancer cells [38]. We detected ROR $\beta$ expression in normal intestinal epithelial cells and intestinal tumors; moreover, $R O R B$ was also decreased in cancer tissues, suggesting that the distribution of ROR $\beta$ may be more widespread than is currently known and that ROR $\beta$ may play a role as a tumor suppressor. Similar to $\mathrm{ROR} \alpha$ and ROR $\gamma, \mathrm{ROR} \beta$ contains 4 functional domains, including an amino-terminal A/B domain, a DNA-binding domain (DBD), a hinge region, and a carboxy-terminal LBD [39, 40]. The DBD is highly homologous between ROR $\beta$ and ROR $(92 \%)$, but the LBD is not well conserved among RORs [41]. ROR $\beta$ includes ROR $\beta 1$ and ROR $\beta 2$ isoforms. ROR $\beta 1$ and ROR $\beta 2$ are characterized by different $\mathrm{A} / \mathrm{B}$ domains that contain 2 and 13 amino acids, respectively. The $\mathrm{N}$-terminal $2^{\text {nd }}-13^{\text {th }}$ amino acids of ROR $\beta 1$ are replaced by an arginine in ROR $\beta 2$ [42]. The molecular function of ROR $\beta$ needs to be further clarified. ROR $\beta$ is considered to be a critical transcription factor regulating rod differentiation $[43,44]$. ROR $\beta 1$ induces the expression of the early key transcription factors Ptf1a and Foxn 4 and promotes the differentiation of amacrine and horizontal cells [45]. ROR $\beta$ also regulates bone formation by inhibiting Runx2 activity [36]. There is relatively little evidence supporting a functional relationship between the ROR $\beta$ and Wnt activities related to the self-renewal of CCICs. It has been reported that ROR $\alpha$ binds to the promoter region of CTNNB1 to inhibit Wnt activity [46], which is involved in a non-canonical Wnt pathway. Among the target molecules of NRIP2, ROR $\beta$ is homologous to ROR $\alpha[42,47]$, but whether ROR $\beta$ affects the Wnt pathway remains unclear. Here, we show that ROR $\beta$ suppresses the Wnt pathway and unlike ROR $\alpha, \operatorname{ROR} \beta$ neither binds with $\beta$-catenin nor affects its transcription.

ROR $\beta$ is a DNA transcription enhancer. Thus, we screened for target genes at the transcriptional level, enabling the discovery of $\mathrm{HBP} 1$ as an interaction partner. ROR $\beta$ enhances the transcription of $H B P 1$ by binding to its HRE region upstream promoter. HBP1 belongs to the sequence-specific, HMG family of transcription factors [48]. As a putative suppressor of the Wnt pathway, HBP1 may also inhibit the transcription of TCF4 targets by directly blocking the binding of TCF4 with DNA [33, 49]. Therefore, we speculate that ROR $\beta$ may affect the activity of the Wnt pathway by regulating HBP1 transcription,

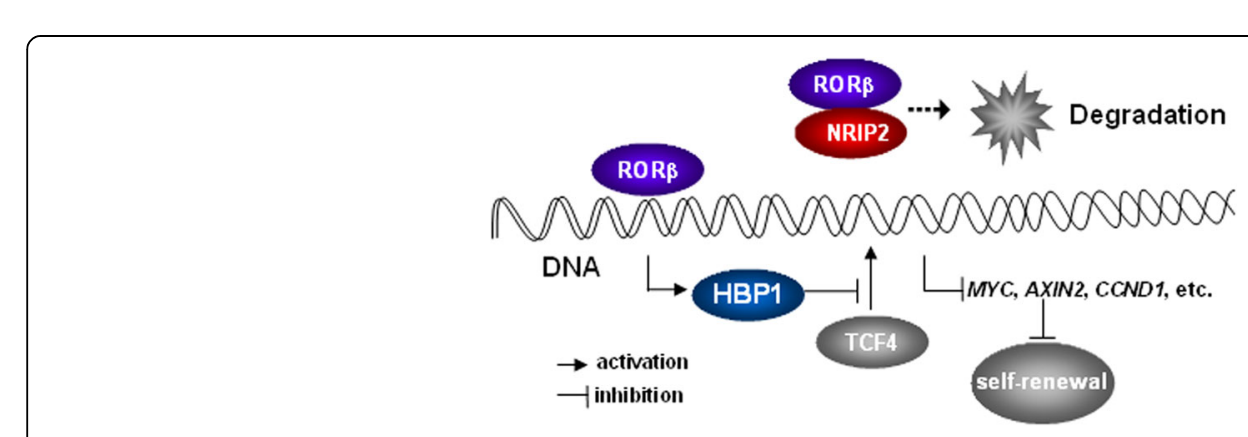

Fig. 7 Illustration of interaction between NRIP2, RORß, and HBP1 
and NRIP2 up-regulates Wnt activity by attenuating ROR $\beta$ transcriptional activity. Due to the critical role of the Wnt pathway in CCIC self-renewal, HBP1 also participated in the regulation of CCIC self-renewal. These results indicate that the NRIP2/ROR $\beta / \mathrm{HBP} 1$ pathway is a beneficial supplement to the Wnt pathway. In addition to the activation of the Wnt pathway by NRIP2/ROR $\beta / \mathrm{HBP} 1$, NRIP2 is also associated with DNA mismatch repair in colorectal cancer cells, and ROR $\beta$ may be correlated with tumorigenesis and tumor stages (Additional file 2), suggesting that the NRIP2/ROR $\beta / \mathrm{HBP} 1$ pathway is also involved in other biological processes.

\section{Conclusion}

In this study, we identified NRIP2 as a novel molecule acting in Wnt pathway. The interaction between NRIP2 and ROR $\beta$ activates downstream target HBP1 and is probably involved in CCIC self-renewal. For the positive role in Wnt, NRIP2 may be a potential alternative target for inhibiting CCIC self-renewal.

\section{Additional files}

Additional file 1: Determination of NRIP2 and HBP1 in the colorectal cancer initiating cells and detection of RORB in the colorectal epithelials. (DOC $3098 \mathrm{~kb}$ )

Additional file 2: Analysis of the relationship between NRIP2, RORB and clinical parameters. (DOCX $1238 \mathrm{~kb}$ )

\begin{abstract}
Abbreviations
CCICs: Colorectal cancer initiating cells; ChIP: Chromatin immunoprecipitation; Co-IP: Co-immunoprecipitation; CSC: cancer stem cell; Dvl: Disheveled; EMSA: Electrophoretic mobility shift assay; ES: Embryonic stem cells; FACS: Fluorescence-activated cell sorting; FISH: Fluorescence in situ hybridization; GSEA: Gene set enrichment analysis; GSK-3ß: Glycogen synthase kinase-3 $\beta$; HBP1: HMG box-containing protein 1; HMG: High-mobility-group; HRE: Hormone response elemen; IHC: Immunohistochemical; iPS: Induced pluripotent cells; LEF: Lymphoid enhancer factor; LRP5/6: Low-density lipoprotein receptor-related protein 5/6; NRIP2: Nuclear receptor-interacting protein 2; ROR2/PTK7: Receptor tyrosine kinase-like orphan receptor 2/protein tyrosine kinase 7; RORB: Retinoic acid-related orphan receptor $\beta$; SP: Side population; TCF: T-cell factor
\end{abstract}

\section{Acknowledgments}

We thank Mr. Qinghua Lu and Ms. Qi Dong at Cancer Institute and Education Ministry Key Laboratory of Cancer Prevention and Intervention, Zhejiang University School of Medicine for FCM and confocal microscopy analysis. We also thank Professor Douglas Forrest and Dr. Hong Liu at Laboratory of Endocrinology and Receptor Biology, National Institute of Diabetes, Digestive and Kidney Diseases, National Institutes of Health for providing tissue samples from Rorb ${ }^{-1-}$ knockdown transgenic mice.

\section{Funding}

This work was partly supported by grants from National Science of Foundation Committee of China [81472723; 81602586; 81071768], Natural Science Foundation of Zhejiang Province [LY14H160023, LY15H160040] and Foundation of Scientific Technology Bureau of Zhejiang Provience [2012C37105; 2013C33117].

\section{Availability of data and material}

The datasets generated during and/or analysed during the current study are available from the corresponding author on reasonable request.

\section{Authors' contributions}

ZW, YZ and JM conceived and designed the study. All authors participated in the experiments and collaboratively in drafting the manuscript. SY, HT, YZ, DX, WS, XL and JM contributed to data acquisition, ZW, TP, JW and YW performed analysis and interpretation of data. ZW, TP. JL, YZ and JM revised the manuscript. All authors read and approved the final manuscript.

\section{Competing interests}

We declare that we have no competing interests.

\section{Consent for publication}

Not applicable.

Ethics approval and consent to participate

All fresh primary colorectal cancer tissues were collected in the Second Affiliated Hospital of the Zhejiang University School of Medicine, with Institutional Review Board approval and informed consent provided by the patients (Reference number: R2014-041).

\section{Author details}

${ }^{1}$ Laboratory of Gastroenterology, Second Affiliated Hospital of Zhejiang University School of Medicine, Jiefang Road 88\#, Hangzhou, Zhejiang 310009, China. ${ }^{2}$ People's Hospital of Huangyan district, Taizhou, Zhejiang 318020, China. ${ }^{3}$ People's Hospital of Putuo district, Zhoushan, Zhejiang 316100, China. ${ }^{4}$ Department of Molecular Pharmacology, Beckman Research Institute, City of Hope, Duarte, CA 62232, USA. ${ }^{5}$ Cancer Institute and Education Ministry Key Laboratory of Cancer Prevention and Intervention, Zhejiang University School of Medicine, Hangzhou, Zhejiang 310009, China. ${ }^{6}$ Present address: Department of Gastroenterology, Sir Run Run Shaw Hospital of Zhejiang, University School of Medicine, Hangzhou, Zhejiang 310016, China.

Received: 6 October 2016 Accepted: 17 January 2017

Published online: 31 January 2017

\section{References}

1. Edge SB, Compton CC. The american joint committee on cancer: the 7th edition of the AJCC cancer staging manual and the future of TNM. Ann Surg Oncol. 2010;17:1471-4.

2. O'Brien CA, Pollett A, Gallinger S, Dick JE. A human colon cancer cell capable of initiating tumour growth in immunodeficient mice. Nature. 2007;445:106-10.

3. Vaiopoulos AG, Kostakis ID, Koutsilieris M, Papavassiliou AG. Colorectal cancer stem cells. Stem Cells. 2012;30:363-71.

4. Dalerba P, Cho RW, Clarke MF. Cancer stem cells: models and concepts. Annu Rev Med. 2007:58:267-84.

5. Schneider M, Huber J, Hadaschik B, Siegers GM, Fiebig HH, Schuler J. Characterization of colon cancer cells: a functional approach characterizing CD133 as a potential stem cell marker. BMC Cancer. 2012;12:96.

6. Kemper K, Grandela C, Medema JP. Molecular identification and targeting of colorectal cancer stem cells. Oncotarget. 2010;1:387-95.

7. Radtke F, Clevers $\mathrm{H}$. Self-renewal and cancer of the gut: two sides of a coin. Science. 2005;307:1904-9.

8. Ricci-Vitiani L, Lombardi DG, Pilozzi E, Biffoni M, Todaro M, Peschle C, De Maria R. Identification and expansion of human colon-cancer-initiating cells. Nature. 2007:445:111-5.

9. Gao F, Zhang Y, Wang S, Liu Y, Zheng L, Yang J, Huang W, Ye Y, Luo W, Xiao D. Hes1 is involved in the self-renewal and tumourigenicity of stem-like cancer cells in colon cancer. Sci Rep. 2014;4:3963.

10. Bu P, Chen KY, Chen JH, Wang L, Walters J, Shin YJ, Goerger JP, Sun J, Witherspoon M, Rakhilin N, et al. A microRNA miR-34a-regulated bimodal switch targets Notch in colon cancer stem cells. Cell Stem Cell. 2013;12:602-15.

11. Whissell G, Montagni E, Martinelli P, Hernando-Momblona X, Sevillano M, Jung P, Cortina C, Calon A, Abuli A, Castells A, et al. The transcription factor GATA6 enables self-renewal of colon adenoma stem cells by repressing BMP gene expression. Nat Cell Biol. 2014;16:695-707.

12. Varnat F, Duquet A, Malerba M, Zbinden M, Mas C, Gervaz P, Ruizi AA Human colon cancer epithelial cells harbour active HEDGEHOG-GLI signalling that is essential for tumour growth, recurrence, metastasis and stem cell survival and expansion. EMBO Mol Med. 2009;1:338-51.

13. Tian Q, He XC, Hood L, Li L. Bridging the BMP and Wnt pathways by $\mathrm{PI} 3$ kinase/Akt and 14-3-3zeta. Cell Cycle. 2005:4:215-6. 
14. Lin Y, Yang Y, Li W, Chen Q, Li J, Pan X, Zhou L, Liu C, Chen C, He J, et al. Reciprocal regulation of Akt and Oct4 promotes the self-renewal and survival of embryonal carcinoma cells. Mol Cell. 2012;48:627-40.

15. Krausova M, Korinek V. Wnt signaling in adult intestinal stem cells and cancer. Cell Signal. 2014;26:570-9.

16. Schwitalla S, Fingerle AA, Cammareri P, Nebelsiek T, Göktuna SI, Ziegler PK, Canli O, Heijmans J, Huels DJ, Moreaux G, et al. Intestinal tumorigenesis initiated by dedifferentiation and acquisition of stem-cell-like properties. Cell. 2002;152:25-38.

17. Shenoy AK, Fisher RC, Butterworth EA, Pi L, Chang $\amalg$, Appelman HD, Chang M, Scott EW, Huang EH. Transition from colitis to cancer: high Wnt activity sustains the tumor-initiating potential of colon cancer stem cell precursors Cancer Res. 2012;72:5091-100.

18. van de Wetering M, Sancho E, Verweij C, de Lau W, Oving I, Hurlstone A, van der Horn K, Batlle E, Coudreuse D, Haramis AP, et al. The beta-catenin/ TCF-4 complex imposes a crypt progenitor phenotype on colorectal cancer cells. Cell. 2002;111:241-50.

19. McDonald SL, Silver A. The opposing roles of Wnt-5a in cancer. Br J Cancer. 2009;101:209-14.

20. Carpentino JE, Hynes MJ, Appelman HD, Zheng T, Steindler DA, Scott EW, Huang EH. Aldehyde dehydrogenase-expressing colon stem cells contribute to tumorigenesis in the transition from colitis to cancer. Cancer Res. 2009;69:8208-15.

21. Huang EH, Hynes MJ, Zhang T, Ginestier C, Dontu G, Appelman H, Fields JZ, Wicha MS, Boman BM. Aldehyde dehydrogenase 1 is a marker for normal and malignant human colonic stem cells (SC) and tracks SC overpopulation during colon tumorigenesis. Cancer Res. 2009;69:3382-9.

22. Shtutman M, Zhurinsky J, Simcha I, Albanese C, D'Amico M, Pestel R, Ben-Ze'ev A. The cyclin D1 gene is a target of the beta-catenin/LEF-1 pathway. Proc Natl Acad Sci U S A. 1999;96:5522-7.

23. Tetsu O, McCormick F. Beta-catenin regulates expression of cyclin D1 in colon carcinoma cells. Nature. 1999;398:422-6.

24. Habas R, Dawid IB, He X. Coactivation of Rac and Rho by Wnt/Frizzled signaling is required for vertebrate gastrulation. Genes Dev. 2003;17:295-309.

25. Yamanaka H, Moriguchi T, Masuyama N, Kusakabe M, Hanafusa H, Takada R, Takada S, Nishida E. JNK functions in the non-canonical Wnt pathway to regulate convergent extension movements in vertebrates. EMBO Rep. 2002;3:69-75.

26. Castanon I, Abrami L, Holtzer L, Heisenberg CP, van der Goot FG, GonzalezGaitan M. Anthrax toxin receptor 2a controls mitotic spindle positioning. Nat Cell Biol. 2013;15:28-39.

27. Zallen JA. Planar polarity and tissue morphogenesis. Cell. 2007;129:1051-63.

28. Wang YK, Zhu YL, Qiu FM, Zhang T, Chen ZG, Zheng S, Huang J. Activation of Akt and MAPK pathways enhances the tumorigenicity of CD133+ primary colon cancer cells. Carcinogenesis. 2010:31:1376-80.

29. Marisa L, de Reynies A, Duval A, Selves J, Gaub MP, Vescovo L, EtienneGrimaldi MC, Schiappa R, Guenot D, Ayadi M, et al. Gene expression classification of colon cancer into molecular subtypes: characterization, validation, and prognostic value. PLoS Med. 2013;10:e1001453.

30. Greiner EF, Kirfel J, Greschik H, Huang D, Becker P, Kapfhammer JP, Schule R. Differential ligand-dependent protein-protein interactions between nuclear receptors and a neuronal-specific cofactor. Proc Natl Acad Sci U S A. 2000;97:7160-5.

31. Andre E, Gawlas K, Becker-Andre M. A novel isoform of the orphan nuclear receptor RORbeta is specifically expressed in pineal gland and retina. Gene. 1998;216:277-83.

32. Chow $L$, Levine EM, Reh TA. The nuclear receptor transcription factor, retinoid-related orphan receptor beta, regulates retinal progenitor proliferation. Mech Dev. 1998;77:149-64.

33. Sampson EM, Haque ZK, Ku MC, Tevosian SG, Albanese C, Pestell RG, Paulson KE, Yee AS. Negative regulation of the Wnt-beta-catenin pathway by the transcriptional repressor HBP1. EMBO J. 2001;20:4500-11.

34. Krylov DM, Koonin EV. A novel family of predicted retroviral-like aspartyl proteases with a possible key role in eukaryotic cell cycle control. Curr Biol. 2001;11:R584-587.

35. Gabriely G, Kama R, Gelin-Licht R, Gerst JE. Different domains of the UBL-UBA ubiquitin receptor, ddi $\mathrm{Nsm1}$, are involved in its multiple cellular roles. Mol Bio Cell. 2008;19:3625-37.

36. Komori T, Yagi H, Nomura S, Yamaguchi A, Sasaki K, Deguchi K, Shimizu Y, Bronson RT, Gao YH, Inada M, et al. Targeted disruption of Cbfa1 results in a complete lack of bone formation owing to maturational arrest of osteoblasts. Cell. 1997;89:755-64.
37. Muhlbauer E, Bazwinsky-Wutschke I, Wolgast S, Labucay K, Peschke E. Differential and day-time dependent expression of nuclear receptors RORa, RORb, RORg and RXRa in the rodent pancreas and islet. Mol Cell Endocrinol. 2013:365:129-38.

38. Risinger Jl, Allard J, Chandran U, Day R, Chandramouli GV, Miller C, Zahn C, Oliver J, Litzi T, Marcus C, et al. Gene expression analysis of early stage endometrial cancers reveals unique transcripts associated with grade and histology but not depth of invasion. Front Oncol. 2013;3:139.

39. Giguere V. Orphan nuclear receptors: from gene to function. Endocr Rev. 1999;20:689-725.

40. Jetten AM, Kurebayashi S, Ueda E. The ROR nuclear orphan receptor subfamily: critical regulators of multiple biological processes. Prog Nucleic Acid Res Mol Biol. 2001;69:205-47.

41. Flores MV, Hall C, Jury A, Crosier K, Crosier P. The zebrafish retinoid-related orphan receptor (ror) gene family. Gene Expr Patterns. 2007:7:535-43.

42. Carlberg C, Hooft van Huijsduijnen R, Staple JK, DeLamarter JF, Becker-Andre M. RZRs, a new family of retinoid-related orphan receptors that function as both monomers and homodimers. Mol Endocrinol. 1994;8:757-70.

43. Jia L, Oh EC, Ng L, Srinivas M, Brooks M, Swaroop A, Forrest D. Retinoid-related orphan nuclear receptor RORBeta is an early-acting factor in rod photoreceptor development. Proc Natl Acad Sci U S A. 2009;106:17534-9.

44. Oh EC, Khan N, Novelli E, Khanna H, Strettoi E, Swaroop A. Transformation of cone precursors to functional rod photoreceptors by bZIP transcription factor NRL. Proc Natl Acad Sci U S A. 2007;104:1679-84.

45. Liu H, Kim SY, Fu Y, Wu X, Ng L, Swaroop A, Forrest D. An isoform of retinoid-related orphan receptor beta directs differentiation of retinal amacrine and horizontal interneurons. Nat Commun. 2013;4:1813.

46. Lee JM, Kim IS, Kim H, Lee JS, Kim K, Yim HY, Jeong J, Kim JH, Kim JY, Lee H, et al. RORalpha attenuates Wnt/beta-catenin signaling by PKCalphadependent phosphorylation in colon cancer. Mol Cell. 2010;37:183-95.

47. Du L, Yang $X$, Yang L, Wang $X$, Zhang A, Zhou H. Molecular evidence for the involvement of ROR and ROR in immune response in teleost. Fish Shellfish Immunol. 2012:33:418-26.

48. Lesage F, Hugnot JP, Amri EZ, Grimaldi P, Barhanin J, Lazdunski M. Expression cloning in $\mathrm{K}+$ transport defective yeast and distribution of HBP1, a new putative HMG transcriptional regulator. Nucleic Acids Res. 1994;22:3685-8.

49. Elfert S, Weise A, Bruser K, Biniossek ML, Jagle S, Senghaas N, Hecht A Acetylation of human TCF4 (TCF7L2) proteins attenuates inhibition by the HBP1 repressor and induces a conformational change in the TCF4:: DNA complex. PLoS One. 2013;8:e61867.

\section{Submit your next manuscript to BioMed Central and we will help you at every step:}

- We accept pre-submission inquiries

- Our selector tool helps you to find the most relevant journal

- We provide round the clock customer support

- Convenient online submission

- Thorough peer review

- Inclusion in PubMed and all major indexing services

- Maximum visibility for your research

Submit your manuscript at www.biomedcentral.com/submit
) Biomed Central 